DOI: $10.14451 / 2.151 .11$

\title{
КОЛЛЕГИАЛЬНЫЕ И ЕДИНОЛИЧНЫЕ ОРГАНЫ В СИСТЕМЕ ПУБЛИЧНОГО ПРЕДСТАВИТЕЛЬСТВА В РОССИИ
}

\author{
(c) 2021 Зайцева Елизавета Евгеньевна \\ студент-магистрант \\ Юридическая Школа ДВФУ, Россия, Владивосток \\ E-mail: zalizaveta98@mail.ru \\ (c) 2021 Баранова Вероника Алексеевна \\ студент-магистрант \\ Юридическая Школа ДВФУ, Россия, Владивосток \\ E-mail: nikazlaya97@mail.ru \\ (c) 2021 Кешишян Александра Вагаршаковна \\ студент-магистрант \\ Юридическая Школа ДВФУ, Россия, Владивосток \\ E-mail: alekasndrak@mail.ru
}

В содержании настоящей научной статьи авторами исследуется вопрос о понятии органов в системе публичного представительства на территории Российской Федерации, а также рассматриваются их отдельные виды: как коллегиальные, так и единоличные. По завершению исследования авторы формулируют значимые и итоговые выводы.

Ключевые слова: коллегиальные органы, единоличные органы, система публичного представительства, Россия, виды, понятие.

Актуальность выбранной темы исследования обусловлена, в первую очередь, тем, что в настоящий период времени практическая реализация публичной власти, единственным источником которой является российский народ, осуществляется посредством функционирования представительных органов, действующих в его интересах. В связи с этим, теоретическая разработка особенностей отдельных видов органов в системе публичного представительства в России представляется крайне значимой и необходимой, ведь это не только соответствует действующей Конституции РФ [1], но и позволяет выявлять существующие проблемы их функционирования, а также своевременно разрешить их.

Сама дефиниция «органов в системе публичного представительства» не имеет легально закрепленного определения, что вынуждает при ее толковании обратиться к положениям отечественной правовой доктрины. Так, Н. В. Варламова под «органами государственной власти» понимает органы, наделённые публично-властными полномочиями, которые проистекают из акта народного волеизъявления, осуществляемого посредством свободных, демократических выборов [2].
Не углубляясь в существующую в юридической науке полемику по данному вопросу, можно выделить наиболее существенные признаки свойственные данным органам. Так отличительными особенностями данного органа является самостоятельное выражение политической воли и получение полномочий непосредственно от избирателей. Данный признак характерен для современных государств и в первую очередь присущи президенту, главе субъекта федерации и муниципального образования, если они избираются населением органам законодательной власти субъектов федерации, выборным коллегиальным органам автономных образований, наделенных законодательными полномочиями, выборным коллегиальным органам регионального и местного самоуправления.

Исходя из вышеизложенного, можно выделить органы публичного представительства двух видов: коллегиальные и единоличные. Основой данной классификации является количественный состав органов государственной власти, и речь в данном контексте не о количестве конкретных лиц, занятых в деятельности коллегиального органа, а в способе принятия решений. Так, Единоличный орган принимает решения 
самостоятельно, на основе личного императивного волеизъявления, а коллегиальный, как правило, путем подсчета большинства голосов, принятых в соответствии с нормативно правовыми актами, регулирующие сферу, то есть компетенцию данного органа.

Авакьян С.А. отмечает, что двойственность политического представительства на одном и том же территориальном уровне несет в себе элемент конфликта или по меньшей мере противоречий между соответствующими органами, в частности, между главой государства и парламентом и, как правило, когда в каком-либо государстве сразу несколько органов власти наделены правом представлять суверенный народ, баланс сил всегда складывается в пользу того органа, чей демократический характер кажется более очевидным его гражданам [3].

Коллегиальные органы представляются более демократическими, собственно, только они и являются подлинно представительными органами, причем именно в силу своей коллегиальности, что говорит о наличии политического плюрализма, то есть существование, как минимум двух различных взаимосвязанных, но одновременно автономных мнений, взглядов, позиций, что отражает интересы различных групп общества. Таким образом только наличие коллегиального органа может представлять не только доминирующие, соответствующие действительности социальные интересы, но и весь их спектр.

Коллегиальность органа уже из своего названия презюмирует наличие решений, которые олицетворяют свободную и публичную дискуссию, в ходе которой все его члены участвуют на формально равных основаниях. При этом едва ли не все избиратели (за незначительным исключением) могут сказать, что в парламентской дискуссии принимали участие их представители, те, за кого они голосовали на выборах. Только в таких условиях избранные представители могут формировать и выражать политическую волю нации.

Коллегиальность органов является своеобразной защитой от «сосредоточения власти в одних руках», то есть от принятия управленческих решений, которые зависят от конкретного лица субъективно. Так, например, нормативноправовые акты высшего уровня всех развитых стран, регулирующие наиболее важные общественные отношения, принимаются посредством широкого многоступенчатого коллегиального рассмотрения в парламентах. В судебной системе коллегиальное принятие решений используется как инструмент системы обжалования в апелляционной и надзорных инстанциях, где рассмотрение поступивших жалоб реализуется судьями коллегиально. Так по принципу коллегиальности строятся такие органы власти, как - Государственная Дума России - 450 депутатов, Бундестаг ФРГ - 496 депутатов, Палата представителей Конгресса США - 435 представителей.

Таким образом, коллегиальный представительный орган является наиболее демократическим институтом для осуществления законодательной функции. Нормативно-правовой акт - это не любой закон, исходящий от государства получивший соответствующее название, а акт, принятый коллегиальным представительным органом в рамках строго установленной процедуры, то есть законодательного процесса, ибо право, как регулятор общественных отношений должно формироваться в рамках открытого, гласного законного, политического процесса, который предоставляет равный доступ к законотворчеству всем носителям социальных интересов» [4]. Как уже было отмечено выше законодательный процесс - это сложный механизм, который включает в себя, применительно к Российской Федерации четыре стадии, состоящих из трех чтений законопроекта. На каждой из стадии реализуются определенные цели и задачи, однако основными целями данных законодательных стадий является обеспечение законности, целесообразности, и соблюдения принципа плюрализма мнений при принятии нормативного парового акта.

Таким образом, резюмируя изложенное, в условиях современной России, существование единоличных и коллегиальных органов представительства публичной власти продиктовано необходимостью построения правового и демократического государства, однако преимущественной моделью для построения представительного органа власти является их коллегиальность. 


\section{Библиографический список}

1. Конституция Российской Федерации: принята всенародным голосованием 12.12.1993 // Рос. газета. 1993.25 декабря. Собр. законодательства Рос. Федерации. 2014. № 9. Ст. 851 (с учетом поправок от 21.07.2014).

2. Варламова Н.В. Представительные органы публичной власти: содержание понятия // Труды Института государства и права Российской академии наук. 2012. № 1. С. 5.

3. Авакьян С. А. Конституционное право России. М: Проспект, 2010. С. 495-496.

4. Четвернин В.А. Демократическое конституционное государство: введение в теорию. М.: Норма, 1993. С. 89. 